\title{
Kosovar Identity: Challenging Albanian National Identity
}

\author{
LEANDRIT I. MEHMETI \\ University of South Australia \\ Leandrit.Mehmeti@unisa.edu.au
}

\begin{abstract}
The debate on development of Kosovar identity, initiated after the war of 1998-99 in Kosovo, began initially promulgating the differences of Albanian language dialects to give voice to the new political circumstances after the declaration of independence. The main argument of this debate revolves around two extremes: the existence or non-existence of the Kosovar identity as a national identity. Such a debate is seen as a challenge to Albanian identity. This article argues that both these positions hold some valid reasoning, however the development of an identity into a national one is a much more complex premise than dialectical differences in speech or the existence of an independent state. The article discusses how Albanian identity is still powerful for the majority of the Kosovo population and examines the prospects of the Kosovar identity to replace the power of the Albanian identity. The article concludes that Kosovar identity contains many favourable ingredients to develop as a national identity, however it is still soon to be considered one and that such development depends on political circumstances, mostly international and less national.
\end{abstract}

\section{Introduction}

Albanian national identity developed through different phases throughout its history experiencing different challenges. Many factors like isolation, political systems, religion/s, ${ }^{1}$ education and inter-ethnic relations with other nations of the Balkans, played particular and important roles in the shaping and development of national identity. ${ }^{2}$ However, the most important factor that shaped the way Albanian identity developed in the Balkans is the fact that more than half of the Albanian population found itself living outside of the nation-state of Albania following the dissolution of the Ottoman Empire in late $19^{\text {th }}$ and early $20^{\text {th }}$ century. 3

\footnotetext{
${ }^{1}$ Albanians are a multi-religious society.

${ }^{2}$ N. Clayer, Në fillimet e nacionalizmit shqiptar: Lindja e një kombi me shumicë myslimane në Evropë, translated from French by Artan Puto, Marin Barleti Tiranë, 2012; I. Blumi, 'The Role of Education in the Formation of Albanian Identity and its Myths', in Schwandner-Sievers, S. \& Fischer B.J. (eds) Albanian Identities: Myth and History, Indiana University Press, Bloomington \& Indianapolis, 2002, pp. 49-59.

3 This article will not cover the historical developments that led to the establishment of the nation-states in the Balkans in the late $19^{\text {th }}$ and early $20^{\text {th }}$ centuries, following the break-up of the Ottoman Empire. There is a vast literature on historic developments as well as about the distribution of the Albanian population throughout the Balkans and the circumstances how they remained outside of their established nation-state. See for example: J. Mertus, Kosovo: How Myths and Truths Started a War, University of California Press, 1999; G. Duijzings, Religion and the Politics of Identity in Kosovo, London: Hurst \& Company, 2000; N. Malcolm, Kosovo: A Short History (Updated with a New Preface), New York: New York University Press, 1999; H. Poulton and M. Vickers, "Kosovo Albanians: Ethnic Confrontation with the Slavic State," in H. Poulton and S. Taji-Frouki (eds.), Muslim Identity and the Balkan State, London: Hurst \& Co, 1997; Arshi Pipa and Sami Repishti, eds., Studies on Kosova, Boulder: East European Monographs, 1984; Charles Jelavich and Barbara Jelavich, The Establishment of the Balkan National States, 1804 - 1920, Seattle, WA: University of Washington Press, 1977; Edwin E Jacques, The Albanians: An Ethnic History from Prehistoric Times to the Present, NC and London: McFarland \& Co 1995
} 
The promoters of the Kosovar identity as national one, approach this debate through the framework of Universalist theories emphasising the universal characteristic of modern state and its relationship to group identities. The canonical works of Gellner, Smith, Anderson or Hobsbawm are the foundation used to build the thesis of the Kosovar national identity. 4 However, as Eriksen points out the strengths of these approaches suggesting that they need to be supplemented with the experiential world of the everyday life of the actors (Lebenswelt), 5 in the context of Kosovo this is of paramount relevance in terms of flexibility and the fluidity of the character of the human identification. Discussing the development of the Kosovar identity, a combination of different criteria such as language, ethnicity, political demands for greater autonomy or independence, history, institutionalism, subjective imagination, ${ }^{6}$ voluntarism or invention, 7 are relevant.

The process of the development of the Kosovar identity stands between two paradigms. The first paradigm notes that Kosovar national identity is being created and/or constructed as a consequence of the new political circumstances after the declaration of independence. As such this incorporates a particular approach of the analysis that would consider the development of state and institutions as necessary ingredients that would develop and combine with the incorporation of particular feelings of belonging that would lead to a process of nation-building (state-building) by consciousness-raising. As observed by Hobsbawm, ${ }^{8}$ insisting on consciousness or choice as the criterion of nationhood is insensible while subordinating the complex and multiple ways in which people and/or individuals define and redefine themselves as members of groups, to a single option: the choice of belonging to a 'nation' or 'nationality'. The second paradigm contradicts these approaches, in view of the consequences and challenges that such developments may have for Albanian national identity by excluding a great number of Albanians (who do not necessarily identify themselves as Kosovar Albanians) living outside of today's Albania and Kosovo.

Viewing Kosovar identity in the perspective of nationalism as defined by Gellner, who holds that "nationalism is primarily a political principle, which holds that the political and national unit should be congruent", 9 requires a more careful examination with regards to distinguishing other elements of understanding and the making of nations, incorporating elements such as invention or social engineering. ${ }^{10}$ In this sense Kosovar identity does not seem natural as the political and national unit do not seem to be congruent simply because the national unit remains the Albanian identity while the political unit remains the independent Kosovo which includes other different ethnicities, the majority of which consider themselves as Albanians. However, if one views 'nation' as something fluid, dynamic and in constant flux, due to changes in

\footnotetext{
4 E. Gellner, Nations and Nationalism, Cornell University Press, New York, Paperback edition, 2008; A. Smith, National Identity, Penguin, Harmondsworth, 1991; B. Anderson, Imagined Communities: Reflections on the Origin and Spread of Nationalism, Verso, London/New York, Revised Edition, 2006; Anderson, op. cit.; E. J. Hobsbawm, Nations and Nationalism since 1780, Cambridge University Press, New York, $2^{\text {nd }}$ edition, 1992 Hobsbawm, op. cit.

5 T.H. Eriksen, 'Ethnic Identity, National Identity and Intergroup Conflict: The Significance of Personal Experiences', in R. D. Ashmore, L. Jussim and D. Wilder (eds) Social Identity, Intergroup Conflict, and Conflict Reduction, Volume 3, Oxford University Press, Oxford, 2001, pp. 42-68, p. 62

${ }^{6}$ Anderson, op. cit.

7 Hobsbawm, op. cit

8 ibid., p. 8

9 Gellner, op. cit., p. 1

10 ibid., pp. 47-49
} 
social and political alternatives, rather than as an unchanging static entity, then Kosovar identity does seem to have some basis from which to evolve.

This paper analyses the assertion of existence or non-existence of the Kosovar identity as a national one, viewed as challenging the Albanian national identity. The article argues that Kosovar identity does have solid potential to evolve into a national one, however this process is characterised with more complexities than language dialect differences or even the existence of the Kosovo state. The article is organised in three sections. The first section examines the Albanian identity, providing a brief view of its formation and empowerment and its effect on Albanians living in the Socialist Federal Republic of Yugoslavia (SFRY). The second section explores the premises promulgated in the debate about the development of Kosovar identity through the Albanian language dialect differences. The final section examines the prospects of the development of Kosovo identity as a national one following the new political circumstances after the declaration of independence of Kosovo.

\section{Albanian national identity}

Albanian nationalism did develop in similar political contexts and in a similar period of time, as did all other nationalisms in the Balkans. ${ }^{11}$ However, there were differences in the ways in which these nationalist ideas were constructed or manifested and how nationalism was used to construct a nation and a nation-state. What can be considered as a late development in Albanian nationalism and hence in Albanian national identity is the distribution of such nationalistic ideas throughout the Albanian population in the Balkans and the use of such ideas to create a unified awareness of a common national identity. ${ }^{12}$ The lack of a single cultural or even religious administrative centre that would serve as a mechanism for the construction, engineering and distribution of national codes, symbols, myths or history, impacted the development of national identity. ${ }^{13}$

Political circumstances related to social circumstances created the conditions for such social change, as it is generally understood through the terms of a specific ideology of the European tradition of understanding of nationalism stating that each nation should possess its own state or at least some degree of territorial selfdetermination. ${ }^{14}$ Such a prospect is hard to apply in the context of Albanians living under the Ottoman rule because the state was nonexistent and there was no centrally organised mechanism in the form of either religion or state.

Religion for Albanians did not play the role it did for other nations of the Balkans, due to the fact that Albanians have a very relaxed attitude towards religion in general. Albanian national identity is built on elements such as language, culture and history, while religion still remains only an individual way of expressing a spiritual consciousness rather than an identification. The Albanian intellectual elites of $19^{\text {th }}$ and early $20^{\text {th }}$ centuries viewed religion as problematic for the development of national identity. Constructing a national identity based on religion was simply seen

\footnotetext{
${ }^{11}$ Clayer, op. cit., p. 637

12 ibid., pp. 637-640

13 P. Misha, 'Invention of a Nationalism: Myth and Amnesia', in S. Schwandner-Sievers, \& B. J. Fischer (eds) Albanian Identities: Myth and History, Indiana University Press, Bloomington \& Indianapolis, 2002 , pp. 33-48. p. 37

14 L.E. Cederman, 'Nationalism and Ethnicity', in Carlsnaes, W., Risse, T \& Simmons, B.A. (eds), Handbook of International Relations, Sage, London, 2002, pp. 409-428. p. 411
} 
as dangerous, dysfunctional and unrealistic based on the political, social and religious situation of Albanians in the Balkans. Dangerous because such an identification would not create a national identity but quite the contrary would divide Albanians and prevent the development of a common identity due to the risk of being marginalised in already established religious identifications in the Balkans. Such an identification would leave out a significant part of the same population (and territories) that used Albanian as their mother tongue. Dysfunctional because Albanians had failed to establish national centres of religious management or administration. Unrealistic because religious identification would cause confusion and perhaps ideological and social anarchy due to the fact that the struggles for freedom that created myths, legends and heroes were national and not religious. The attitude and the approach of the "Religion of Albanians is Albanian-ism" a verse from the poem "Oh Albania, Poor Albania" by Pashko Vasa, a prominent Albanian figure, Ottoman Governor of Lebanon (catholic by religion), published in 1881 by Jan Urban Jarník, a Czech linguist, ${ }^{15}$ became the slogan and the phrase that was fated to become the most famous and used phrase in Albanian contemporary history. ${ }^{16}$ Albanian culture, the feeling of common kinship and especially the Albanian language became the central elements of Albanian nationalism. ${ }^{17}$ These elements remained strongly in use especially by Albanians living in the SFRY.

The struggle of Albanians in the SFRY and especially of those in Kosovo to have their nation status recognised in federal terms and the political implication and consequently denial of such status within the SFRY strengthened even further the Albanian identity. Having in mind the political circumstances in the SFRY and the differences between them and the surrounding Slavic communities, the general Albanian identification was something natural and an uncompromising social and political element not only in Kosovo but also for Albanians living in the SFRY republics of Montenegro, Serbia and Macedonia. In this context Kosovar identity existed merely as a regional identity that Albanians living in Kosovo would use to emphasise a closer geographical identification between themselves. Albanian national identity was an element that kept the Albanians in the SFRY tied to Albania at least in a virtual and often an emotional way.

Communist Albania created a modern infrastructure to foster the national identity, portraying the communist victory as the main way of protecting Albanianism. However, to do so, other previous elements from history were taken into account, especially elements that would suggest the struggle and the victorious battles to protect anything Albanian, starting from the $15^{\text {th }}$ century struggles against Ottomans to the communist victory in WWII through their partisan struggle. ${ }^{18}$

The isolation of communist Albania impacted the development of Albanian national identity. Despite the policies of unification of Albanian elements of society, through educational development and exchange of literature and educational materials in general, or the unification of the language by a particular standard norm, the isolation of Albania still impacted Albanians living outside Albanian state. They

\footnotetext{
${ }^{15}$ R. Elsie, History of Albanian Literature Vol 2, Columbia University Press, New York, 1995, pp. $262-264$ 16 Clayer, op.cit., p. 257

${ }_{17}$ S. Skendi, The Albanian National Awakening 1878-1912, Princeton University Press, Princeton, 1967, p. 469

18 P. Prifti, Socialist Albania since 1944, Domestic and Foreign Developments, MIT Press, Cambridge, 1978, pp. $12-20$
} 
developed in different political, social and economic circumstances. These differences started to surface more after the fall of communism and the opening of Albania.

\section{Albanian language dialect differences}

Albanian language has two main dialects, Southern (Tosk dialect) and Northern (Gheg dialect). Writings in Albanian appeared first in the northern dialect and later in both dialects throughout the centuries until the language was finally standardised in 1972 in the Congress for the Standardisation of the Language held in Tirana. The basis of the standard language was to be the Southern dialect, despite an initial idea to amalgamate Gheg and Tosk.

This standardisation resulted in a common written language to be used by all Albanians in the world. However, the use of this standard in the spoken speech is extremely limited even today. The debate on the Albanian standard language 'mistakes' and the 'injustices', done to the northern dialect of Gheg, started to appear in late 1980 s at the academic level. ${ }^{19}$ The standard language and the dialect differences have triggered a great debate, especially in Kosovo, about the standard language not serving the main purpose of its establishment, that of unifying the nation in one spoken and written language. This debate brought about many personalities that concurred with the premise that the standard language did not serve its ultimate purpose of unification of the people and called for a possible revisit of the standard or a standardisation of the Gheg dialect. It also provoked a considerable opposition. Kristo Frasheri, an Albanian historian, argued that the possibility of two dialects becoming two standards would lead to the creation of two national identities similar to Serbs and Croats. ${ }^{20}$

These differences have led to an element of differentiation between Albanians in the two countries in terms of 'them' and 'us'. Whether this seems to be the beginning of a very long journey towards a new identity remains to be seen. Hobsbawm notes that multiple identities lies behind even national homogeneity. ${ }^{21} \mathrm{He}$ uses the example of Germans and their identification according to regions or 'tribes', considering themselves as being Saxons, Swabians or Bavarians or members of a German principality or state, but with a single standard written language. ${ }^{22}$

Viewing the emergence of the Kosovar identity based on the differences of the dialects does not seem to cover all complex elements that a national identity would require but seems to limit it to a regional identity. How such identity can be maintained to a regional level or develop to a national one, depends a lot on political and economic circumstances that play a crucial role in the development of a particular sense of belonging.

\section{Kosovar (national) identity}

The debate about Kosovar national identity is relatively new and encouraged after the Kosovo war of 1998-99. It is mainly carried on through discussions in the media

\footnotetext{
19 A. Pipa, The Politics of Language in Socialist Albania, Boulder: East European Monographs, 1989 ${ }^{20}$ Koha Ditore, Kristo Frashëri: Dy standard na çojnë në 2 kombe, si serbët e kroatët, 5 May 2014, http://archive.koha.net/?id=4\&l=8851, accessed on 20 April 2017

${ }^{21}$ E.J. Hobsbawm, "Language, Culture and National Identity", Social Research, Vol. 63, No. 4, pp. 1065-108o, p. 1067

22 ibid. pp. 1067-1068
} 
throughout Albanian space in the Balkans but also in the academic level, albeit limited. Two most vocal figures engaged in this discussion in Kosovo are Nexhmedin Spahiu, a scholar, and Halil Matoshi, philosopher and journalist. Spahiu discussed the development of Kosovar identity into a national one more extensively in his book 'Towards Kosovar Nation' where he defines the nation as a 'capable society to establish a state'. ${ }^{23} \mathrm{He}$ considers the building of Kosovar national identity as a political enterprise modifying and adjusting aspects of Albanian culture and national symbols to Kosovo circumstances. ${ }^{24}$ Matoshi on the other hand, seems to take a stronger position about the process of the development of the Kosovar identity into a national one inviting to distinguish between the concepts of civic and ethnic national identity, therefore the political and cultural identities. ${ }^{25} \mathrm{He}$ sees the Kosovar identity on practical terms that contributes to the strengthening of the Kosovo independence providing other non-Albanian communities a sense of belonging to a multiethnic state. Matoshi does not suggest that the development of Kosovar identity into a national one will automatically translate into the non-existence or dismissal of the Albanian ethnicity as this sentiment will continue to exist, however the strengthening of Kosovar identity based on citizenry will only mean compatibility with an ever globalised and multicultural world. ${ }^{26}$

This debate however, has triggered a very strong opposition to such claims. The counter argumentations to these theses mainly hold that Kosovar identity exists only as a regional one and as an integral part of the larger Albanian identity ${ }^{27}$ and that the loyalty towards the Kosovar identity means abandonment from the loyalty of the Albanian identity. ${ }^{28}$ The debate is powerful enough to provoke emotional responses especially from many of those who oppose such claims often qualifying those who defend such claims as anti-Albanians. Consequently, it often leads to misreading the original positions presenting those as efforts to replace the Albanian identity with an artificial Kosovar identity ${ }^{29}$ reminiscent of the old Yugoslav identity, doomed to failure. 30

The engagement in opposing of the Kosovar national identity thesis attracted also some reputable Kosovo academics such as Rexhep Qosja and Mehmet Kraja. Qosja is more comprehensive in his analysis and views the development of the Kosovar national identity in terms of the idea of the national unification ${ }^{31}$ and considers such 'Kosovarisation' as a counter-historical ideology that ultimately challenges the very core basis of the Albanianism that has shaped the history of Albanian people since

\footnotetext{
${ }^{23}$ N. Spahiu, Drejt Kombit Kosovar, Mitrovica: Botim Privat, 2004, p. 3

24 Ibid., pp. 5-7

25 H. Matoshi, "Kosova: Ndërtimi (i vështirë) i një kombi’, Shenja, 2 October 2016, http://shenja.tv/kosova-

ndertimi-i-veshtire-i-nje-kombi/, accessed on $20^{\text {th }}$ April 2017

${ }^{26}$ H. Matoshi, 'Identiteti kulturor Kosovar është evropian dhe kozmopolitan', Reporteri, 10 August 2012,

http://reporteri.net/?page $=1,7,410$, accessed on 21 ${ }^{\text {st }}$ April 2017

27 V. Murati, 'A ekziston identiteti Kosovar?', Shekulli, 17 May 2004

${ }_{28}$ M. Krasniqi, 'Për identitetin: Shqiptar apo Kosovar?', Kosovain, 18 June 2012,

http://kosovain.eu/sq/Opinione/14076, accessed on 20 ${ }^{\text {th }}$ April 2017

29 B. Bislimi, 'Identiteti Kosovar, real apo artificial', Radio Evropa e Lirë, 28 November 2011,

http://www.evropaelire.org/a/24404415.html, accessed on $20^{\text {th }}$ April 2017

$3^{\circ}$ X. Bislimi, 'Kombi” i Jugokosovareve të sojit Halil Matoshi', Kosovapress, 20 May 2016,

http://www.kosovapress.com/sq/opinione/xhevatbislimi/kombi-i-jugokosovareve-te-sojit-halil-matoshi-73487/, accessed on $20^{\text {th }}$ of April 2017

${ }^{31}$ National unification here is meant the unification of geographical space where ethnic Albanians make up the majority of population with Albania proper. This is a completely different wide topic, which is not covered in this paper.
} 
the Prizren League in 1878 to present. ${ }^{22}$ Kraja, on his voluminous book 'Kosovar Identity' offers limited sourced explanations to counter argument the thesis of the Kosovar national identity mostly tautologically suggesting that this identity as such will not survive despite the contemporary efforts to construct one just as the Yugoslav identity did not survive within Albanians in Kosovo.33 In turn, the defenders of the Kosovar identity strengthened their claims to extremes to suggest that the identity is already developed and that now with the consolidation of the state of Kosovo such identity will only empower in the future.

Both these positions hold valid points. An entity that is bound to a particular political territory and a consolidated state does have all the potential to develop into a national identity. Kosovo case does have its own particularities and the Albanian identity was closely tied up to the majority population of Kosovo since this identity was conceived in the $19^{\text {th }}$ century. The development of the Kosovar identity may turn into a national one but as a consequence could require that the Albanian one becomes obsolete. This is something that requires time and is closely depended on the political circumstances. The numerous attempts to define a nation through a variety of theories required that such theories are adjustable to different circumstances many nations went throughout their journeys to develop and strengthen the sentiment of national identity. A particular theory is validated on certain given circumstances.

Many who contribute to the Kosovar national identity debate seem to follow Weber's definition of the 'nation' as 'a community of sentiment, which would adequately manifest itself in a state of its own' and that would 'tend to produce a state of its own'. 34 Such an approach requires a more careful examination as often the coincidence of the state and the nation should be treated as a historical contingency rather than a case of conceptual unity. 35 Another perspective to consider is the intersubjective understanding of belonging that the diversity of human language creates through print technology ${ }^{6}$ (or digital communication) today. Such a perspective leads to the creation of a particular 'social construction of reality'. ${ }^{37}$ Such approaches pose different questions. How do Kosovo Albanians imagine themselves? If they imagine themselves as Kosovars, where is the position of the Albanian identity in such an imagining? Are all ethnic communities of Kosovo included in such identification? Further investigation and empirical studies are required in order to build a better understanding for such questions.

The University of Oslo conducted an empirical study on the creation of national identities in 2011 in the Western Balkans. $3^{8}$ The findings were published in Albanian also. 39 The survey of this study, conducted in the second half of 2011, engaged 1389 respondents, of Albanian ethnicity. The survey found that $83 \%$ of respondents wished that the future of Kosovo were a fully independent state without any international supervision, $3 \%$ with international supervision and only $14 \%$ as united with

${ }^{2}$ R. Qosja, Ideologjia e shpërbërjes: trajtesë mbi idetë çintegruese në shoqërinë e sotme shqiptare, Toena, Tiranë, 2006, p. 49

33 M. Kraja, Identiteti Kosovar: publicistikë, PEN Qendra e Kosovës, Prishtinë, 2011, p. 199

34 M. Weber, From Max Weber: Essays in Sociology, Oxford University Press, New York, 1946, p. 176

35 W. Connor, Ethnonationalism: The Quest for Understanding, Princeton University Press, Princeton, 1994

${ }^{36}$ Anderson, op. cit. p. 46

37 P. Berger and T. Luckmann, The Social Construction of Reality: A Treatise in the Sociology of Knowledge, Anchor Books, New York, 1967

${ }^{8} 8$ P. Kolstø, (eds), Strategies of Symbolic Nation-building in South Eastern Europe, Routledge, London \& New York, 2016

39 Kombformimi simbolik në Evropën juglindore, Qendra për Hulumtime dhe Politikë Gjinore, Prishtinë, 2013 
Albania. 40 On the statement that they agree that there is a Kosovo nation, 23\% disagreed (fully or mostly) and $63 \%$ agreed (fully or mostly). ${ }^{41}$ However, respondents primarily would identify themselves as Kosovo Albanians 55\%, Kosovars $26 \%$ and Albanians 19\%. $4^{2}$ The Kosovar Institute for Policy Research and Development (KIPRED) published a study in 2016, on the impact of religion on the ethnic identity where they conducted a public opinion analysis. 43 The survey engaged 1000 respondents of Albanian ethnicity. In the question 'Which from these categories describe best how you feel?' 44\% responded as Albanian then Kosovar, 32\% Kosovar then Albanian, $17 \%$ Albanian and 7\% Kosovar. 44 This change of public opinion in 5 years suggests that the existence of Kosovar national identity remains blurry, due to Albanian identity being in a central position and due to the fact that Kosovo is still not consolidated as a stable political and economic entity.

Albanian identity remains very strong in Kosovo mostly because the relations with Serbia are often hostile. In a hostile political environment, the regional identity diminishes in importance in comparison with the national one while in a secure political and prosperous economic environment identities tend to be more fluid and open to change. With regards to Kosovo relations with the outside world the hypothesis of Kosovo national identity seems to be strengthened. Kosovo as an independent entity with its own national/state symbols is another element that cannot be ignored. Despite the fact that the Kosovo flag and other state symbols do not represent any Albanian symbolism, "reflecting its multi-ethnic character" as per the Ahtisaari Plan 45 and the initial hesitation of Albanians to use them, still these symbols are used every day, strengthening the Kosovar citizenship factor. Ahtisaari Plan, which is the basis of the Kosovo constitution, envisaged establishing a Kosovar political identity based on citizenry and citizenship. Pula, however, argues that this is not the case as this concept prejudges the ethnicity and categorises every individual as members of specific 'communities' while not even acknowledging the 'community' as a nation in miniature. 46

Officially, the citizens of Kosovo are called Kosovars, including all minorities living in Kosovo. In terms of the citizenship Kosovar identity is a national one representing the state identity. This is the beginning of the new national identity with the perspective to be strengthened with time. Wendt notes that given the importance of identities, a classification of theories should be able to represent different 'levels of construction'. 47 In such a perspective, the Albanian identity in Kosovo still remains strong and it seems that it will continue to be so for a period of time, although one can never be certain that such an identity is not on the move. The nationalists' primordial ideological construction that the Albanian nation is a naturally given entity is seriously challenged.

$4^{0}$ IPSOS Strategic Market, 'Report - Nation Building: Kosovo', 2011,

http://www.hf.uio.no/ilos/forskning/prosjekter/nation-w-balkan/dokumenter/nb_kosovo.pdf, p. 52

${ }^{41}$ Ibid., p. 76

${ }^{42}$ Ibid., p. 77

43 KIPRED, 'What happened to Kosovo Albanians: The impact of religion on the ethnic identity in the statebuilding period', Policy Paper, No. 1/16, June 2016,

http://www.kipred.org/repository/docs/What_happened_to_Kosovo_Albanians_740443.pdf

44 Ibid., p. 72

45 UNSC, Comprehensive Proposal for the Kosovo Status Settlement, 26 March 2007, General Principles, Article 1.7. p.2, www.unosek.org/docref/Comprehensive_proposal-english.pdf accessed on 27th February 2017

${ }^{6} 6$ B. Pula, 'Kush e konstituon shtetin e Kosovës? Qytetaria dhe komuniteti në Kosovën Ahtisaariane', Identiteti Evropian i Kosovës: simpozium ndërkombëtar, i mbajtur më 26 dhe 27 Qershor 2007 në Prishtinë, Prishtina: Forum2015, 2007, pp. 109-112, p. 110

47 A. Wendt, Social Theory of International Politics, Cambridge University Press, Cambridge, 1999, p. 244 
The debate in Kosovo, however, should also consider other aspects of identity formation such as instrumentalist terms following March and Olsen's 'logic of consequences' 48 emphasizing identity reproducing institutions. While instrumentalists view identities as fluid and subject to free individual choice, the institutionalists, in contrast, seem to be more prone to regard identity as being ascribed (through a constitutional framework) rather than chosen, in a way locking individuals into a path-dependent collective identification process. 49 Analysing the emergence of the Kosovar identity a combination of both these perspectives seems in order. Firstly, acknowledge that the national identity is a changing process. Secondly, institutions play an important role in the consolidation and strengthening of national identity. People in Kosovo today identify with those institutions and such identification will only be strengthened in the future.

Another aspect to be taken into account is the history of Kosovo Albanians over the last two decades and their struggle for freedom from Serbian rule. This is significant in the sense of national awareness and national feelings of sacrifice and struggle for physical survival. As such the struggle for independence, i.e. for the creation and establishment of a new state, is another important element to consider when discussing national identity. Kosovar Albanians are proud of such a political and historical achievement. The element of pride, inter-related to the element of sacrifice, is also an important factor when it comes to the construction or the imagining of national identity. In this sense Kosovar national identity in political terms will continue to be present and strengthen with time.

\section{Conclusions}

The presence of the debate on Kosovar identity speaks for itself if such a process is developing. Whether Kosovar identity will develop as a regional, political, legal or national identity depends on internal, regional and international political developments that may affect it. The successful consolidation of the Kosovo state with prosperous economic perspective where its citizens can look forward to proudly identify with may eventually enable the Kosovar identity to form as a national identity. ${ }^{\circ}$ The position that Kosovar identity today is a national identity may be a premature conclusion mostly because Kosovo state is still in its initial phase of consolidation and has yet a long journey to develop as a sustainable independent state. Moreover, the Kosovo state continues to be contested and its perspective to join the EU is solid but very unclear, given the developments within the EU itself. The questions that Anthony D. Smith asked back in 1992 whether the European identity as a supranational political identity, in the form of the EU, will come to conflict with national ones in times of crisis seem to have a great degree of relevance today. ${ }^{51} \mathrm{In}$ the context of the Kosovar identity with any possible competing identities in times of crisis it may be premature and intellectually indefensible to suggest that the power of

\footnotetext{
48 J.G. March \& J.P. Olsen, "The Institutional Dynamics of International Political Orders”, International Organisations, Vol. 52, No. 4, Autumn 1998, pp. 943-969, pp. 949-951

49 C. Calhoun, Nationalism, University of Minnesota Press, Minneapolis, pp. 30-33, from L.E. Cederman, "Nationalism and Ethnicity" in W. Carlsnaes, T. Risse \& B.A. Simmons (eds), Handbook of International Relations, Sage, London, 2002, pp. 409-428, p. 412

50 A. Andersen, 'The Kosovar Identity and Statehood', in Identiteti Evropian i Kosovës: simpozium ndërkombëtar, i mbajtur më 26 dhe 27 Qershor 2007 në Prishtinë, Prishtina: Forum2015, 2007, pp. 105-108, p. 105

${ }^{1}$ A. D. Smith, 'National Identity and the Idea of European Union', International Affairs, Vol. 68, No. 1, January 1992, pp. 55-76, p. 56
} 
Albanian identity would not prevail. The more this consolidation is challenged by regional and international politics that creates any sort of insecurities the Albanian national identity will remain more powerful.

The experiences of the Albanian population in the SFRY have constantly been characterised with violent identity politics including episodes of ethnic cleansing in the last Kosovo war. The relevance of such experiences is mainly related to the strengthening of the Albanian identity. Consequently, for such identity to be more flexible and fluid and evolve into a particular Kosovo national identity the new state of Kosovo must experience a considerable period of political stability, security and economic progress as well as an institutional life that is closely connected to the people. However, the very long struggle of identity politics experienced by the Albanian population in the SFRY may be also used as a symbol of the establishment of the new Kosovar national identity if manifested in a successful consolidation of the Kosovo political and economic independence. To read Zygmunt Bauman in reverse when he discusses the fluid character of human identification and points out that "If the modern 'problem of identity' is how to construct an identity and keep it solid and stable, the postmodern 'problem of identity' is primarily how to avoid fixation and keep the options open',52 in Kosovo context the open options may not mean new identity by the old identity. Today Kosovo has different political and social circumstances. National identity in Kosovo may still be imaginary however; the chances seem to be great that this will change with time. 